\title{
Pemberdayaan Kesehatan Mandiri Santri Melalui Teknologi Budidaya Toga Berbasis Peningkatan Imun Tubuh di Pondok Pesantren Aliyah Nurul Islam Sekarbela
}

\author{
Husnul Jannah*, Iwan Doddy Dharmawibawa, Baiq Muli Harisanti, Agus Muliadi, \\ Sri Nopita Primawati \\ Universitas Pendidikan Mandalika, Jl. Pemuda No. 59 A, Mataram, 83125 Indonesia \\ Email Korespondensi: husnuljannah@ikipmataram.ac.id
}

\section{Diterima: Maret 2020; Revisi: April 2020; Diterbitkan: Mei 2020}

\begin{abstract}
Abstrak
Kegiatan pengabdian ini bertujuan untuk memberikan pengalaman pribadi bagi santri, ustadz dan ustadzah Pondok Pesantren Aliyah Nurul Islam Sekarbela dalam menerapkan pola hidup sehat dalam kehidupan sehari-hari. Adapun tahap-tahap pelaksanaan kegiatan pengabdian ini meliputi tahap pendahuluan berupa kegiatan pembukaan dan tahapan inti berupa pemberian materi tentang tananamtanaman herbal dan pola hidup sehat, dan pembuatan minuman sehat. Kegiatan ini diikuti oleh 45 santri. Hasil kegiatan menunjukkan bahwa santri sangat aktif dalam diskusi selama penyampaian materi, dan antusiasn dalam pembuatan minuman dan penanaman tanaman obat. Berdasarkan hasil kegiatan yang dilakukan, dapat disimpulkan bahwa pengetahuan santri akan pola hidup sehat dan tanaman obat kesehatan keluarga yang dapat berperan sebagai imunomodulator dalam upaya meningkatkan system imunitas ditemukan meningkat.
\end{abstract}

Kata Kunci: kesehatan mandiri; budidaya toga; imunitas

\section{Independent Health Empowerment of Santri through Toga Cultivation Technology Based on Increasing Immunity at the Aliyah Nurul Islam Islamic Boarding School Sekarbela}

\begin{abstract}
This service activity aims to provide personal experiences for santri, ustadz and ustadzah of the Aliyah Nurul Islam Sekarbela Islamic Boarding School in implementing a healthy lifestyle in everyday life. The stages of the implementation of this service activity include the preliminary stage in the form of opening activities and the core stage in the form of providing material on herbal plants and healthy lifestyles, and making healthy drinks. This activity was attended by 45 students. The results of the activity showed that the students were very active in discussions during the delivery of the material, and were enthusiastic in making drinks and planting medicinal plants. Based on the results of the activities carried out, it can be concluded that the knowledge of students about healthy lifestyles and family health medicinal plants that can act as immunomodulators in an effort to increase the immune system was found to be increasing.
\end{abstract}

Keywords: independent health; toga cultivation; immunity

How to Cite: Jannah, H., Dharmawibawa, I., Harisanti, B., Muliadi, A., \& Primawati, S. (2020). Pemberdayaan Kesehatan Mandiri Santri Melalui Teknologi Budidaya Toga Berbasis Peningkatan Imun Tubuh di Pondok Pesantren Aliyah Nurul Islam Sekarbela. Lumbung Inovasi: Jurnal Pengabdian kepada Masyarakat, 5(1), 23-29. doi:https://doi.org/10.36312/linov.v5i1.461

d.

https://doi.org/10.36312/linov.v5i1.461

\section{PENDAHULUAN}

Merebaknya Virus Corona yang lazim disebut Covid 19, Virus ini berasal dari Negara Cina tepatnya di Wuhan yang menjadikan heboh dunia karena penyebarannya yang bersifat 
Pandemi. Indonesia salah satu Negara yang terkena Covid 19 yang diumumkan presiden pada tanggal 2 Maret 2020. NTB juga termasuk salah satu profinsi yang terdampak. Berdasarkan info dari situs resmi pemerintah NTB, kasus positif pertama di NTB pada tanggal 29 Maret 2020 dengan 2 orang positif, 24 pasien dalam pengawasan dan 708 orang dalam pemantauan. Saat ini tepatnya tanggal 19 April 2020 berdasarkan sumber yang sama jumlah pasien positif Cov 19 di NTB sebanyak 72 orang ( 57 orang aktif, 11 orang sembuh dan 4 orang meninggal) (Pemprov NTB, 2020).

Keeadaan tersebut menjadikan masyarakat dalam kondisi ketakutan dan kepanikan karena penyebarannya sangat cepat, hingga harus segera dapat diantisipasi. Terutama untuk santri yang hidup di lingkungan pondok pesantren. Pondok pesantren merupakan salah satu lembaga pendidikan nonpormal. Di mana santri mendapatkan kegiatan belajar mengajar seperti mengaji, beribadah, diskusi dan bersosialisasi antar penghuni dan pengurus pesantren.Dalam suatu pondok, berkumpul banyak santri dengan latar belakang dan kebiasaan atau perilaku kebersihan yang berbeda sehingga lingkungan menjadi berisiko terhadap transmisi penyakit (Tajiri, 2011).

Selain itu fasilitas dan prasarana pondok juga dapat menjadi sumber penyakit bagi santri yang tinggal dilingkungan tersebut.Seperti kebersihan kamar tidur santri, tempat mandi dan lingkungan pondok menyebabkan kemungkinan tertularnya suatu penyakit sangat besar.Penyakit yang saat ini banyak dikeluhkan santri di MA Nurul Islam adalah penyakit yang disebabkan parasite, jamur, bakteri dan virus. Semua jenis penyakit ini dapat disembuhkan dan dikendalikan penyebarannya dengan cara meningkatkan system imunitas dan kesehatan mandiri dengan menerapkan perilaku hidup bersih oleh santri setiap harinya. Diharapkan dengan perilaku hidup bersih dan sehat bisa terbentuk apabila ada proses dimana seseorang berinteraksi antara orang satu dengan yang lain serta dengan lingkungannya.

Fungsi sistem imun bagi tubuh ada tiga yaitu (1) pertahanan tubuh yakni menangkal "benda" asing; (2) keseimbangan fungsi tubuh terutama menjaga keseimbangan komponen yang tua, dan (3) pengintai (surveillence immune system), untuk menghancurkan sel-sel yang bermutasi atau ganas. Pada prinsipnya jika sistem imun seseorang bekerja optimal, maka tidak akan mudah terkena penyakit, sistem keseimbangannya juga normal (Paranita, 2020).

Perubahan perilaku dalam satu lingkungan komunitas atau kelompok membutuhkan upaya yang tidak mudah.Perubahan perilaku dibentuk dari yang awalnya negatif atau tidak tahu menjadi tahu atau paham, kemudian diiringi dengan sikap yang terwujud dalam kemauan berubah yang kuat atau efikasi diri, yang pada muaranya adalah mampu melakukan perubahan.Bagaimana membuat tahu, mau dan mampu (pengetahuan, sikap dan tindakan) dalam pesantren ini merupakan suatu problematika tersendiri. Oleh sebab itu perlu diadakannya pemberdayaan kesehatan mandiri santri melalui teknologi budidaya toga berbasis peningkatan imun tubuh di pondok pesantren aliyah nurul islam sekarbela

Berdasarkan hasil berdiskusi dan melakukan observasi langsung dengan santri dan ustadz serta ustadzah di MA Nurul Islam Sekarbela dapat diambil kesimpulan bahwa penyakit yang saat ini banyak dikeluhkan santri adalah penyakit yang disebabkan parasite, bakteri dan virus. Penyakit yang disebabkan oleh parasite seperti infeksi yang disebabkan kutu dan jamur. Selain itu penyakit yang disebabkan bakteri seperti diare, sedangkan penyakit yang disebabkan oleh virus seperti influenza, batuk, penyakit rongga mulut dan demam serta tifus. Namun keterbatasan pengetahuan santri dan ustadz dalam memberi penanganan awal, karena kurangnya pemahaman kesehatan dan pengetahuan tentang tanaman obat menyebabkan penyakit ini tidak dapat sembuh dengan cepat.Bahkan pada beberapa kasus penyakit ini dapat menularkan sesame santri dan keluarga.Ketika santri pulang ke rumah keluarga masing-masing, penyakit ini bisa ditularkan ke anggota keluarga yang ada di rumah.

Banyak factor setelah diamati yang menyebabkan hal di atas dapat terjadi, seperti rendahnya pemahaman pola hidup sehat yang dimiliki santri. Pola hidup yang saat ini diterapkan santri adalah pola hidup yang dibawa dari keluarga masing-masing. Seperti sehabis mandi handuk tidak di jemur di tempat yang panas dan terik. Setelah bangun santri tidak membersihkan tempat tidur, membersihkan lantai kamar dan membuka jendela agar sirkulasi tetap bagus. Ini adalah salah satu pola hidup yang bisa diterapkan secara mandiri oleh santri. 
Selain itu olah raga, berjemur di matahari dan makan makanan yang bergizi merupakan pola hidup yang benar karena dapat meningatkan system imunitas tubuh santri. Jika santri terpapar bakteri ataupun virus pathogen dengan system imun yang kuat dapat menyembuhkan dirinya sendiri.Ataupun harus meminum obat dapat berupa obat herbal dari tanaman Toga yang di tanam di sekitar pondok. Seperti kunyit putih, kunyit kuning, jahe, temulawak, daun sirih, jambu batu dan masih banyak lainnya.

Dengan pengetahuan yang minim dari keluarga baik itu disebabkan oleh pendidikan orang tua santri yang rendah ataupun karena keterbatasan ekonomi yang membuat santri tidak mengerti pola hidup yang sehat. Oleh sebab itu pemberdayaan kesehatan mandiri santri melalui teknologi budidaya toga berbasis peningkatan imun tubuh di Madrasah Aliyah Nurul Islam Sekarbela harus dilakukan. Tanaman-tanaman famili Zingiberaceae yang seringkali ditemukan di pekarangan rumah, kebun, maupun hasil budidaya dapat dimanfaatkan sebagai obat tradisional (Mutaqin et al., 2017) untuk meningkatkan imunitas tubuh santri.

Kegiatan pengabdian ini bertujuan untuk memberikan pengalaman pribadi bagi santri, ustadz dan ustadzah dalam menerapkan pola hidup sehat dalam kehidupan sehari-hari. Peningkatan pengetahuan santri dan ustadz tentang tanaman obat dapat dimanfaatkan untuk diolah menjadi minuman dan makanan yang menyehatkan sehingga dapat menjaga kesehatan santri secara mandiri. Selain itu, tanaman obat yang dipelajari setelah kegiatan ini dapat diolah agar bernilai ekonomis dan memberikan keterampilan berwirausaha kepada santri untuk dapat diterapkan dalam kehidupan masyarakat di masa mendatang.

\section{METODE PELAKSANAAN Koordinasi Kegiatan}

Adapun tahan-tahap koordinasi kegiatan ini meliputi: (a) Sosialisasi dan Pendekatan dengan Murabi, Nurul Islam. Sekaligus mengatur jadwal pelaksanaan, tempat pelaksanaan dan mempersiapkan alat dan bahan yang dibutuhkan selama pengabdian berlangsung; (b) Sosialisasi dan persiapan kegiatan Pengabdian.

\section{Pelaksanaan}

Adapun tahap-tahap pelaksanaan kegiatan pengabdian ini meliputi kegiatan pendahuluan berupa pemberian materi berupa tananam-tanaman herbal dan pola hidup sehat untuk meningkatkan imunitas santri oleh narasumber. Pada tahapan inti dari pemberdayaan kesehatan mandiri santri melalui teknologi budidaya toga berbasis peningkatan imun tubuh adalah pemberian materi tentang tananam-tanaman herbal dan pola hidup sehat untuk meningkatkan imunitas santri. Kemudian dilanjutkan diskusi, pembagian peserta menjadi beberapa kelompok untuk pembuatan minuman sehat yang dapat langsung dipraktekkan oleh santri. Selain itu telah disiapkan beberapa bibit kuniyt, laos dan jahe yang akan di tanam oleh santri sebagai tanaman toga di area pondok pesantren putri Nurul Islam Sekarbela.

\section{HASIL DAN PEMBAHASAN}

Kegiatan pengabdian ini dilakukan selama masa pandemic dengan protokol kesehatan yang ketat. Santri sebelum memasuki ruangan pengabdian disiapkan tempat cuci tangan, sehingga santri harus mencuci tangan terlebih dahulu.Kemudian melakukan absensi pertemuan dan duduk ditempat yang telah di tetapkan.Keterbatasan melakukan kegiatan selama pandemic ini juga menyebabkan lokasi pengabdian berubah dari pelaksanaan di sekolah Mandrasah Aliyah menjadi pelaksanaan di dalam pondok pesantren santri putri Nurul Islam Sekarbela. Kegiatan sekolah yang dilakukan secara daring menyebabkan sekolah menjadi sepi dan siswa lebih aktif di rumah masing-masing.

Kegiatan pengabdian ini dilaksankan selama 1 minggu dengan berbagai tahap pelaksanaan. Dimulai dengan tahap koordinasi kegiatan. Setelah ditetapkan pondok santri putri sebagai temat diadakannya kegiatan pengabdian tim melakukan diskusi dengan Murabi sebagai penanggung jawab kegiatan di pondok pesantren putri seperti disajikan pada Gambar 1. Diskusi meliputi waktu kegiatan, tempat pelaksanaan kegiatan dan jumlah santri putri yang ikut serta terkait protokol kesehatan. 


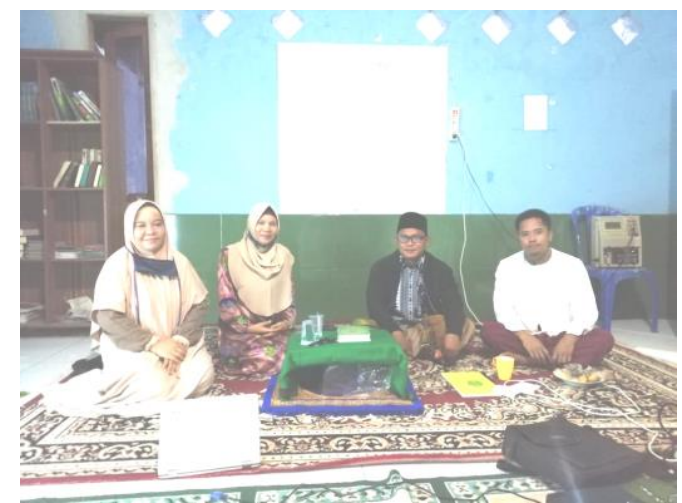

Gambar 1. Silaturahmi dengan Murabbi di Pondok Pesantren Putri Nurul Islam

Pelaksanaan kegiatan inti dilakukan hari jumat sore di aula pondok putri dengan melibatkan 45 orang santri dan para Mudabbir, Ustadz dan Ustadzah. Gambar 2 menunjukkan kegiatan pemaparan materi tentang apa itu system kekebalan tubuh (imunitas), fungsi kekebalan tubuh dari benda asing (antigen) yang berasal dari lingkungan baik itu virus ataupun bakteri, kemudian tanaman herbal yang dapat meningkatkan system imun tubuh sehingga tanpa minum obat kimia pun tubuh manusia dapat menyembuhkan dirinya sendiri.

Pada tahap ini santri diajak untuk mempelajari dirinya sendiri dengan mencontohkan system imun pada tubuh santri jika rendah maka akan cepat terinfeksi bakteri mau pun infeksi virus dari lingkungan. Misalkan untuk jerawat di masa pubertas dan flue atau batuk sebagai penyakit yang paling sering di temukan di pondok. Flue dan batuk dapat disembuhkan sendiri oleh tubuh karena manusia sebagai mahluk paling sempurna diciptakan Allah dilengkapi dengan system pertahan sendiri yang disebut imunitas. Santri di ajak berdiskusi terkait sakit flue atau batuk dapat disembuhkan tanpa menggunakan obat, dengan menekankan pola hidup sehat seperti istirahat yang cukup, makan seimbang dan minum obat-obat tradisional yang banyak ditemukan di lingkungan pondok ataupun rumah tangga.

Seperti halnya dengan jeruk nipis yang diminum dengan air hangat dapat menghancurkan dahak-dahak yang terdapat di saluran pernafasan. Jika dahak tersebut keluar semua maka tubuh akan sembuh dan tidak batuk lagi tanpa harus meminum obat kimia. Selain itupada kesempatan ini juga di jelaskan manfaat tanaman lain sebagai imnomodulator (meningkatkan system imun) seperti : jinten hitam (Nigella sativa L), lidah buaya (Aloe vera L), laos (Alpinia galanga), kunyit (Curcuma domestica), jahe (Zingiber officinale), kencur (Kaemferia galanga), kunyit putih (Curcuma zedoaria), temulawak (Curcuma xanthorrhiza Roxb),tanaman echinacea (Echinacea purpurea), meniran (Phyllantus niruri), mengkudu (Morinda citrifolia L.), jeruk nipis (Citrus aurantifolia s).

Hasil penelitian Medenica et al (1997) dalam Hassan et al (2004) menunjukkan bahwa Nigella sativa $L$. mempunyai aktivitas immunomodulatory kuat dan aktivitas seperti interferon dan mampu menghambat cancer dan progresi sel endothelial dan menurunnya produksi angiogenic, faktor pertumbuhan protein fibroblastic oleh sel tumor.

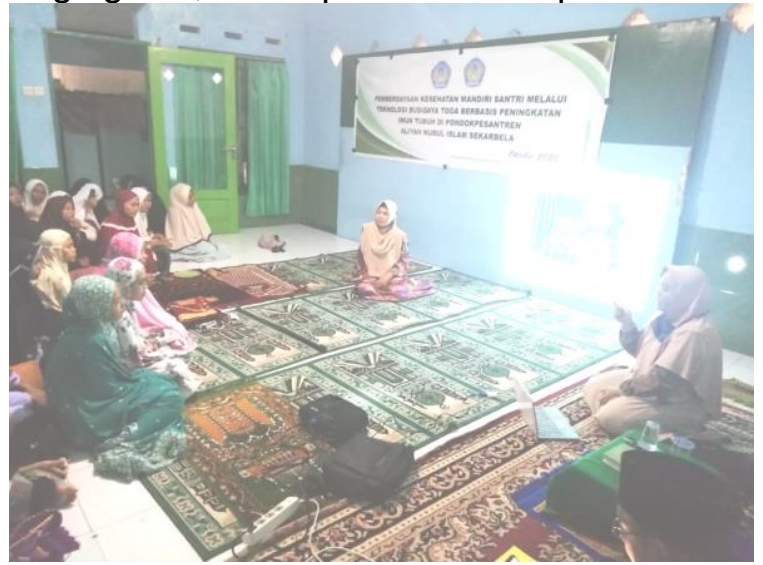

Gambar 2. Penyampaian materi tananam-tanaman herbal dan pola hidup sehat untuk meningkatkan imunitas santr 
Kandungan polisakarida dari A. vera menunjukkan aktivitas immunostimulant, yang berperan sebagi aktivasi adjuvant terhadap produksi antibody spesifik dan meningkatkan pelepasan interleukin-1 (IL-1), interleukin-6 (IL-6), tumor necrosis factor-a (TNF-a), dan interferon-c (INF-c). Pelepasan/release sitokin menstimulasi peningkatan mencapai 300\% dalam replikasi fibroblast pada kultur jaringan dan meningkatkan fogositosis (El-Obeid et al., 2006).

Tanaman echinacea (Echinacea purpurea) memiliki kandungan bahan aktif di dalam echinacealah polisakarida, flavonoid, asam cafein minyak atsiri, poliasetilen, alkilamid dan bahan kimia karakteristik. Polisakarida yang larut air berfungsi sebagai stimulan terhadap ketahanan tubuh (memobilisasi leukosit), memacu aktivitas limfosit, sedangkan komponen lemak yang larut berfungsi untuk meningkatkan fagositosis sel, menginduksi produksi interferon dan merangsang pembentukan fibroblast (Rahardjo, 2015).

Keluarga zingiberaceae atau yang dikenal dengan umbi-umbian bagi masyarakat umum seperti kunyit (Curcuma domestica), laos (Alpinia galanga), jahe (Zingiber officinale), kencur (Kaemferia galanga), kunyit putih (Curcuma zedoaria) dan temulawak (Curcuma xanthorrhiza Roxb) dapat memperbanyak jumlah limfosit, meningkatkan toksisitas sel pembunuh kanker (natural killer), sintesis antibodi spesifik dan merangsang aktivitas makrofag.Curcumin meningkatkan efek terhadap fungsi utama dari sel T, sel natural killer (NK), macrophages dan pada splenocytes total in-vivo (Warshikah, 2016).

Penelitian yang ditelah dilakukan oleh Varalakshmi et al (2008) melaporkan bahwa terjadi peningkatan efek immunomodulatory dalam hewan coba. Studi ini memperkuat bahwa curcumin cukup aman dan dapat digunakan sebagai immunomodulator untuk system immune.Pada tahap penyampaian materi tanaman yang bersifat sebagai imunomodulator terlihat antusias santri dengan berbagai bentuk pertanyaan yang terkait dengan lingkuan sekitar pondok dan masalah-masalah kesehatan yang sering mereka alami. Dari pertanyaan yang muncul terlihat bahwa kesadaran akan pola hidup sehat santri sangat rendah. Seperti jarang menjemur kasur yang digunakan, kebersihan kamar kurang terjaga dan kebersihan pakaian juga. Sehingga narasumber juga menjelaskan pentingnya gaya hidup sehat seperti membersihkan kamar setiap hari, menjemur kasur seminggu sekali, melakukan olah raga setiap pagi hari sebelum melaksankan kegiatan sekolah dan sering mencuci tangan setelah dan sebelum melakukan aktifitas serta yang tidak kalah penting menggunakan masker.

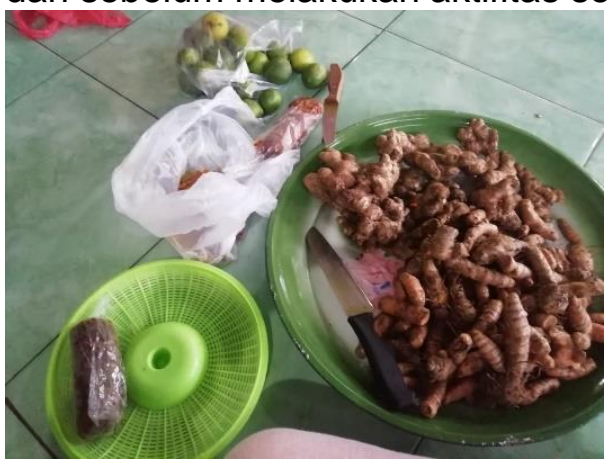

Gambar 3. Proses pembuatan minuman sehat bersama santri putri

Setelah santri paham materi yang di sampaikan santri bersama tim pengabdian melakukan kegiatan pembuatan minuman sehat yang terbuat dari potongan kunyit, jahe, gula merah dan jeruk nipis (Gambar 3). Kunyit, jahe dibersihkan terlebih dahulu dengan air mengalir kemudian di potong-potong kecil. Santri bersama dengan tim pengabdian pertamtama memanaskan air di atas kompor, setelah mendidih potongan kunyit dan jahe dicelupkan bersamaan dengan gula merah. Ditunggu sampai jumlah air rebusan setengah dibandingkan dengan air awal ketika dipanaskan.

Air rebusan dipindahkan kedalam gelas-gelas untuk diberikan kepada santri putri.Jeruk nipis diberikan sesuai selera sehinggi setiap santri memberikan sendiri jeruk nipis kedalam gelas masing-masing.Setelah itu dicicipi dan dibedakan rasa ubuh sebelum dan setelah meminumnya. Santri sebagian besar menyukainya karena hangat, manis gula merah yang tidak terlalu keras dan segar dari air perasan jeruk nipis. Tubuh santri terasa lebih hangat dan segar. 
Melihat proses yang sederhana dan rasa yang nikmat santri merasa mudah membuatnya dan berkeinginan untukmembuatnya dilain hari ketika sebagai minuman sehat pengganti teh atau minuman manis lainnya yang tidak baik bagi tubuh. Bahkan santri yang tidak menyukai jamu mengatakan bahwa minuman sehat yang dibuat segar dan tidak berbau jamu seperti biasanya yang dijual di pasar atau yang keliling.

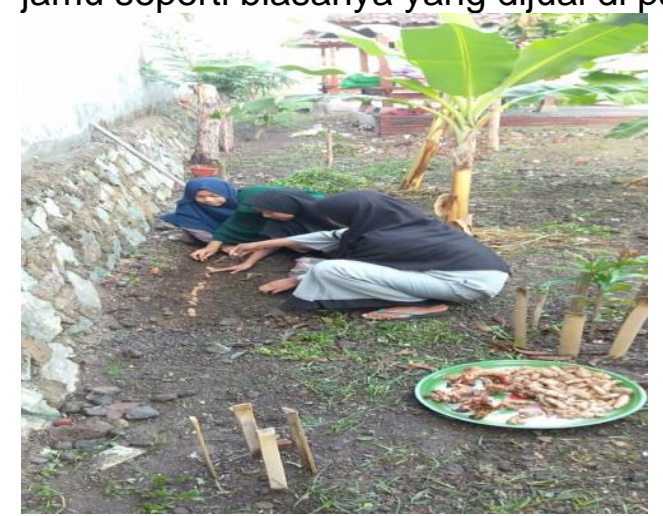

Gambar 4. Proses penanaman bibit tanaman toga untuk dimanfaatkan oleh santri putri

Melihat antusias santri, tim bersama pengurus pondok berinisiatif membuat tanaman obat di sekitar wilayah pondok putri (Gambar 4). Beberapa bibit telah dibeli sebelum pengabdian. Bibit tanaman toga yang sudah di persiapkan meliputi bibit jahe, laos, kunyit dan jeruk nipis. Tujuanya agar ketika santri dan pengurus pondok membutuhkan tanaman tersebut untuk membuat minuman sehat dapat memperoleh dengan mudah.

Bibit tersebut di tanam di sekitar pondok pesantren putri dengan setiap santri menanam sendiri.Tanaman yang mereka tanam adalah tanggung jawab santri.Sehingga setiap santri harus memberi air, merawat tanaman tersebut. Diharapkan selesai pengabdian tanaman toga ini masih dapat dimanfaatkan oleh santri putri dan pengurus pondok pesantren Nurul Islam Sekarbela.

\section{KESIMPULAN}

Dari hasil evaluasi kegiatan, maka dapat disimpulkan bahwa pengetahuan santri akan pola hidup sehat dan tanaman obat kesehatan keluarga yang dapat berperan sebagai imunomodulator dalam upaya meningkatkan system imunitas ditemukan meningkat. Ketercapaian itu terlihat dari antusiasme santri dan pengurus ketika kegiatan pelaksaan pengabdian. Selain itu telah terbentuk apoti hidup di area pondok pesantren dari bibit tanaman toga yang telah dijelaskan manfaatnya sebagai imunomodulator.

\section{REKOMENDASI}

Kegiatan lanjutan yang memanfaatkan tanaman obat tradisional lainnya perlu dilakukan di masa yang akan datang.

\section{UCAPAN TERIMAKASIH}

Tim pengabdian mengucapkan terimakasih kepada LPPM UNDIKMA yang telah mendanai kegiatan ini serta kepada Kepala Asrama dan Pengurus Pondok Pesantren Putri Nurul Islam yang telah mendukung penuh kegiatan ini.

\section{DAFTAR PUSTAKA}

El-Obeid, A., Al-Harbi, S., Al-Jomah, N., \& Hassib, A. (2006). Herbal melanin modulates tumor necrosis factor alpha (TNF- $\alpha$ ), interleukin 6 (IL-6) and vascular endothelial growth factor (VEGF) production. Phytomedicine, 13(5), 324-333. https://doi.org/10.1016/j.phymed.2005.03.007

Gilani, A. H., Jabeen, Q., \& Ullah, M. A. (2004). A Review of Medicinal Uses and Pharmacological Activities of Nigella sativa. Pakistan Journal of Biological Sciences, 7(4), 441-451. https://doi.org/10.3923/pjbs.2004.441.451 
Medenica, R., Janssens, J., \& Tarasenko, A. (1997). Anti-angiogenic activity of Nigella sativa plant extract in cancer therapy. Proceedings of the Annual Meeting of the American Association for Cancer Research, 38.

Mutaqin, A. Z., Nurzaman, M., Setiawati, T., Budiono, R., \& Noviani, E. (2017). Pemanfaatan Tumbuhan Famili Zingiberaceae oleh Masyarakat Sekitar Kawasan Wisata Pantai Rancabuaya Kecamatan Caringin Kabupaten Garut. Sains \& Matematika, 5(2), Article 2. https://journal.unesa.ac.id/index.php/sainsmatematika/article/view/6278

Paranita, E. (2020). Berperan Menjaga Kesehatan, Kenali 3 Fungsi Utama Imunitas. https://www.kompas.com/sains/read/2020/07/24/070200523/berperan-menjagakesehatan-kenali-3-fungsi-utama-imunitas?page=all

Pemprov NTB. (2020). COVID-19 NTB. https://corona.ntbprov.go.id/

Rahardjo, M. (2015). Peluang Pembudidayaan Tanaman Echinacea (Echinacea purpurea) di Indonesia. Perspektif, 4(1), 1-10. https://doi.org/10.21082/p.v4n1.2005.\%p

Tajiri, H. (2011). Integrasi Kognitif dan Perilaku dalam Pola Penanaman Disiplin Santri di Pesantren Al- Basyariah Bandung. Al-Tahrir: Jurnal Pemikiran Islam, 11(2), 415. https://doi.org/10.21154/al-tahrir.v11i2.42

Varalakshmi, Ch., Ali, A. M., Pardhasaradhi, B. V. V., Srivastava, R. M., Singh, S., \& Khar, A. (2008). Immunomodulatory effects of curcumin: In-vivo. International Immunopharmacology, 8(5), 688-700. https://doi.org/10.1016/j.intimp.2008.01.008

Warshikah. (2016). Tumbuhan Zingeberaceae Sebagai Obat-Obatan. Serambi Saintia, 4(1), 35-43. 